\title{
Determinant Factors for Throwing in Competition in Male Elite Handball
}

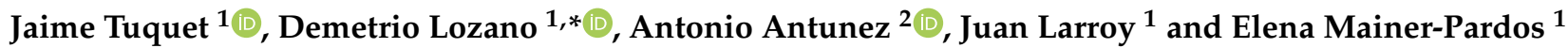 \\ 1 Health Sciences Faculty, Universidad San Jorge, 50830 Zaragoza, Spain; jtuquet@usj.es (J.T.); \\ juanlarroygonzalez@gmail.com (J.L.); epardos@usj.es (E.M.-P.) \\ 2 Research Group in Optimization of Training and Sports Performance (GOERD), University of Extremadura, \\ 10005 Cáceres, Spain; antunez@unex.es \\ * Correspondence: dlozano@usj.es; Tel.: +34-976-060-100
}

Citation: Tuquet, J.; Lozano, D.;

Antunez, A.; Larroy, J.;

Mainer-Pardos, E. Determinant

Factors for Throwing in Competition in Male Elite Handball. Sustainability 2021, 13, 10913. https://doi.org/ $10.3390 /$ su131910913

Academic Editor:

Emilio Villa-González

Received: 20 August 2021

Accepted: 26 September 2021

Published: 30 September 2021

Publisher's Note: MDPI stays neutral with regard to jurisdictional claims in published maps and institutional affiliations.

Copyright: (c) 2021 by the authors. Licensee MDPI, Basel, Switzerland. This article is an open access article distributed under the terms and conditions of the Creative Commons Attribution (CC BY) license (https:// creativecommons.org/licenses/by/ $4.0 /)$.

\begin{abstract}
The aims of this study were to define determinant factors that affected throwing actions used to score goals in handball, and to study the effectiveness of throwing actions and their relationships with different factors during their use, such as: the throwing distance, type of arm build, type of throw, whether it is done while jumping or while supported, the last supporting foot and the previous step cycle, as well as their relationship with the final score of the game in elite male handball competitions. A total of 1049 shots from 24 matches in the 2018/19/20 International Men's Handball Championship were analysed. The results show that distance is relevant in the effectiveness of throwing, setting the build up, throwing while supported or jumping, the type of throwing, the type of steps cycle used and the supporting foot. This seems to indicate that the determining factor that affects a throw is distance.
\end{abstract}

Keywords: sports performance; notational analysis; throwing efficiency; teams sports

\section{Introduction}

The throw used to score a goal in handball is defined as the most important action for success [1]. Determinant factors analysis of handball throwing is focused on variables such as: distance; throwing zone, type, angle or position; the result or final effectiveness of the total quantity of actions [2-4]; or factors of vital importance in the result of the throw, such as speed and accuracy [5-10]. In this line, recent research shows that a shorter throwing distance predetermines the effectiveness $[2,7,11]$. In addition, anthropometric characteristics, throwing velocity [12] and technical-tactical skills are also important for successful participation in elite-level handball [13]. In addition, various articles used the throwing variables as discriminant elements between the winning and losing teams [14-18].

Notational analysis allows us, from an ecological view, to analyse the competition $[19,20]$. In addition, it is necessary to understand the behaviour in these clashes similar to the interaction of dynamic and complex systems, which require the analysis of both individual and collective decision making, considering the context [21-23]. For this reason, many articles focus on match analysis in handball $[8,14,24,25]$.

It is very important to focus on the determinant factors that affect competition throwing in order to focus on the technical learning process in handball. Therefore, we must answer the needs of coaches, who need to know which factors affect the performance of throws in elite handball. Given this context, the aims of the present study were to define determinant factors that affect the throws used to score goals in handball, and to study the effectiveness of throwing actions and their relationships with different factors during their use, such as: the throwing distance, type of arm build, type of throw, whether it is done while jumping or while supported, the last supporting foot and the previous steps cycle, as well as their relationship with the final score of the game in elite male handball competitions. 


\section{Materials and Methods}

The observational methodology enabled data collection directly from the participants in the competition (notational analysis) [20], including analysis of recordings and sequences of the technical-tactical actions of the game in collective sports and its result (match analysis) $[24,25]$. The ethical and deontology principles were met in relation to the participants in the research, and the data obtained was managed according to the ethical principles of the Helsinki 2016 declaration and approved by the Ethics Committee of CEIC Aragón (CEICA) no 10/2021.

\subsection{Participants}

The sample was composed of male elite national teams of the European Championship in 2018, World Championship 2019 and Europe Championship 2020. The teams classified between the first and the fourth were selected. We observed 12 matches. We studied 24 team analyses in the finals, semi-finals and third and fourth place matches. A total of 180 players were analysed (mean age: $27.57 \pm 4.3$ years; body weight: $86.6 \pm 9.9 \mathrm{~kg}$; body height: $1.90 \pm 12.2 \mathrm{~m}$; training experience: 10.1 years; training work: $23.5 \mathrm{~h}$ per week).

\subsection{Instruments}

To analyse the determinant factors affecting throws in elite handball, an ad hoc observation system was designed [20]. It was composed of eight variables and 28 multidimensional categories (Table 1). The computerization of the registry was conducted by the free and versatile software Lince v.1.4 (www.observesport.com, accessed on 24 September 2021) [26]. This program contributes to computerized monitoring procedures that speed up the registry process [27].

Table 1. Variables and descriptions.

\begin{tabular}{|c|c|}
\hline Variable & Description \\
\hline \multirow{5}{*}{ Distance } & $\begin{array}{l}\text { - Six-metre zone }(6 \mathrm{~m}) \text { : Throw done with the last contact of the player } \\
\text { out of the six-metre zone and falling inside and/or invading the air } \\
\text { space of the six-metre area. }\end{array}$ \\
\hline & $\begin{array}{l}\text { Middle zone }(6-9 \mathrm{~m}) \text { : Throw done with the last contact of the player } \\
\text { that performs the action in the middle zone set between the six- and } \\
\text { nine-metre area, without invading the air space of the six-metre area. }\end{array}$ \\
\hline & $\begin{array}{l}\text { - Nine-metre zone }(9 \mathrm{~m}) \text { : Throw done with the last contact of the player } \\
\text { out of the nine-metre zone and falling inside or outside this area. }\end{array}$ \\
\hline & $\begin{array}{l}\text { - Seven-metre zone }(7 \mathrm{~m}) \text { : Throw done in the regulatory action of } \\
\text { seven metres. }\end{array}$ \\
\hline & $\begin{array}{l}\text { - Middle-field zone }(1 / 2) \text { : Throw done with the last contact of the player } \\
\text { in their own middle field. }\end{array}$ \\
\hline \multirow{6}{*}{ Arm positions } & - Overarm throw: Throw done with the arm above the head. \\
\hline & $\begin{array}{l}\text { - Hip throw: Throw done with the arm at the height of the waist on the } \\
\text { throwing arm side. }\end{array}$ \\
\hline & $\begin{array}{l}\text { - Rectified: Throw done with the arm leaning to the opposite side of the } \\
\text { throwing arm. }\end{array}$ \\
\hline & - Back throw: Throw done with his back towards the goal. \\
\hline & - Low throw: Throw done with the hand below the knee. \\
\hline & - Front: Throw done without overarm. \\
\hline
\end{tabular}


Table 1. Cont.

\begin{tabular}{|c|c|}
\hline Variable & Description \\
\hline \multirow{2}{*}{ Jump/Stand } & $\begin{array}{l}\text { - Jump throw: Throw done in the air phase of the jump when the player is } \\
\text { not in contact with the ground. }\end{array}$ \\
\hline & $\begin{array}{l}\text { - Stand throw: Throw done when the player is in contact with the ground } \\
\text { with one of his feet. }\end{array}$ \\
\hline \multirow[b]{2}{*}{ Type of throw } & $\begin{array}{l}\text { Speed throw: Any other type of throwing that is not considered as skill } \\
\text { throwing. }\end{array}$ \\
\hline & $\begin{array}{l}\text { - Skill throw: The player uses some sort of high-level technique such as a } \\
\text { screw (throwing with effect), a topspin throw (a throw in which the ball in } \\
\text { its air path changes its speed) and parabolic throwing. }\end{array}$ \\
\hline \multirow{6}{*}{ Step cycle } & - Zero step: A throw without using any step from the step cycle. \\
\hline & - One step: Throw done after taking a step. \\
\hline & - $\quad$ Two steps: Throw done after taking two steps. \\
\hline & _ $\quad$ Three steps: Throw done after taking three steps. \\
\hline & $\begin{array}{l}\text { - Flying: Throw done when the ball is caught in the air and thrown before it } \\
\text { touches the ground. }\end{array}$ \\
\hline & $\begin{array}{l}\text { - More than three steps: Throw done with more than three steps without } \\
\text { being disciplined for this regulatory violation. }\end{array}$ \\
\hline \multirow{3}{*}{ Foot } & $\begin{array}{l}\text { - Natural: Throw done with the last contact of the player with the floor } \\
\text { being with the opposite foot beside the executing arm. }\end{array}$ \\
\hline & $\begin{array}{l}\text { - Changed: Throw done with the last contact of the player with the ground } \\
\text { being with the foot of the same side of the executing arm. }\end{array}$ \\
\hline & $\begin{array}{l}\text { - Two feet: Throw done with the last contact of the player with the ground } \\
\text { being with both feet simultaneously. }\end{array}$ \\
\hline \multirow{4}{*}{ Results } & $\begin{array}{l}\text { - Goal: A throw that is granted as a goal by the referees due to exceeding the } \\
\text { net line. }\end{array}$ \\
\hline & $\begin{array}{l}\text { - Out: A throw that is not touched by any player of the rival team and ends } \\
\text { out of the net or hits the bars without being a goal. }\end{array}$ \\
\hline & $\begin{array}{l}\text { - Blocked: A throw where the goalkeeper prevents the throw from ending } \\
\text { up in the goal. }\end{array}$ \\
\hline & Defence: Contact/action of the defender on the ball throw. \\
\hline
\end{tabular}

\subsection{Data Validation}

The validation instrument was validated by an expert panel formed by three sports sciences graduates and handball national coaches with research experience in observational methodology [28]. Training of observers was completed thanks to the creation of an observation manual in which variables and the observational process codes were defined [29]. All of the analyses were conducted in a 30-day period using the same tool and in the same space. Two randomly chosen matches were analysed, calculating the intra-observer internal consistency and reliability (at two different times) and inter-observer internal consistency and reliability. The internal consistency and the reliability thresholds, between 0 and 1 [30], were set at: for $\alpha$ (internal consistency), <0.50 unacceptable, $0.51-0.60$ poor, 0.61-0.70 questionable, $0.71-0.80$ acceptable, $0.81-0.90$ good, and $\geq 0.91$ excellent [31]; for ICC (reliability), $\leq 0.50$ poor, $0.51-0.75$ moderate, $0.76-0.90$ good, and $\geq 0.91$ excellent [32]; 
and for $\mathrm{K}$ (reliability) $<0.01$ no agreement, $0.01-0.20$ poor, $0.21-0.40$ discrete/regular, $0.41-$ 0.60 moderate, $0.61-0.80$ good, and $0.81-1.00$ very good [33]. The validation showed the internal consistency and reliability of the intra-observer means as 0.86 , and inter-observer means as 0.91 . Both can be considered good and very good.

\subsection{Statistical Analysis}

Basic statistical descriptors (frequency and percentages) were calculated for each game-related statistic using the match outcome (winning and losing teams). Normality was calculated for each variable using the Kolmogorov-Smirnov test. For the differences between the winning/losing teams, an ANOVA (one factor) test was applied. Additionally, the chi-square test was used to examine the relationship between the variables, where the direction of the relationship was identified using corrected standardized residuals (Zcorrected). A $p$-value $<0.05$ was considered to be statistically significant. The statistical analysis was performed with the software package SPSS version 25.0 (SPSS Inc., Chicago, IL, USA).

\section{Results}

A total of 1049 throws were registered (Table 2). Throws were most frequently made from 6 metres (44.7\%). The most used throwing technique was the classic (93.2\%). Most of the throws were made while jumping $(77.1 \%)$. Most of the throws were at the maximum possible ball speed $(95.7 \%)$. The most frequent throw was made with two steps $(31 \%)$. The total efficacy was $62.2 \%$.

Table 2. Throwing frequency and percentage.

\begin{tabular}{|c|c|c|c|c|c|c|c|}
\hline \multicolumn{2}{|c|}{ Throws Variables } & \multirow{3}{*}{$\begin{array}{c}N \\
548 \\
501\end{array}$} & \multirow{3}{*}{$\begin{array}{c}\% \\
52.2 \% \\
47.8 \%\end{array}$} & \multicolumn{2}{|c|}{ Throws Variables } & \multirow{2}{*}{$\begin{array}{l}n \\
1\end{array}$} & \multirow{2}{*}{$\begin{array}{c}\% \\
0.1 \%\end{array}$} \\
\hline & Winner & & & \multirow{6}{*}{ Overarm } & Low & & \\
\hline Match score & Loser & & & & Hip & 52 & $5 \%$ \\
\hline \multirow{4}{*}{ Distance } & $9 \mathrm{~m}$ & 236 & $22.5 \%$ & & Classic & 978 & $93.2 \%$ \\
\hline & $6-9 \mathrm{~m}$ & 243 & $23.2 \%$ & & In front & 1 & $0.1 \%$ \\
\hline & $6 \mathrm{~m}$ & 469 & $44.7 \%$ & & Back & 4 & $0.4 \%$ \\
\hline & $7 \mathrm{~m}$ & 101 & $9.6 \%$ & & Rectified & 13 & $1.2 \%$ \\
\hline \multirow{2}{*}{ Jump/support } & Support & 240 & $22.9 \%$ & \multirow{4}{*}{ Result } & Block & 46 & $4.4 \%$ \\
\hline & Jump & 809 & $77.1 \%$ & & Out & 94 & $9 \%$ \\
\hline \multirow{2}{*}{$\begin{array}{l}\text { Type of } \\
\text { throwing }\end{array}$} & Strong & 1004 & $95.7 \%$ & & Goal & 653 & $62.2 \%$ \\
\hline & Skill & 45 & $4.3 \%$ & & Saves & 256 & $24.4 \%$ \\
\hline \multirow{3}{*}{$\begin{array}{l}\text { Supporting } \\
\text { foot }\end{array}$} & Changed & 80 & $7.6 \%$ & \multirow{6}{*}{ Steps cycle } & Fly & 10 & $1 \%$ \\
\hline & Two feet & 69 & $6.6 \%$ & & Zero & 182 & $17.3 \%$ \\
\hline & Natural & 900 & $85.8 \%$ & & One & 277 & $26.4 \%$ \\
\hline \multirow{4}{*}{$\begin{array}{l}\text { Result of } \\
\text { throwing }\end{array}$} & Block & 46 & $4.4 \%$ & & Two & 325 & $31 \%$ \\
\hline & Out & 94 & $9 \%$ & & Three & 231 & $22 \%$ \\
\hline & Goal & 653 & $62.2 \%$ & & +Three & 24 & $2.3 \%$ \\
\hline & Saves & 256 & $24.4 \%$ & & Total & 1049 & $100 \%$ \\
\hline
\end{tabular}

Note: m: metres.

The analysis of variance (one-factor ANOVA) regarding variables of ranges with a normal distribution (Table 3) did not show significant differences between the average of the different championships and the quantity of throws (1.890 f; $0.176 \mathrm{sig}$ ) and their effectiveness ( $0.542 \mathrm{f} ; 0.590 \mathrm{sig}$ ). 
Table 3. Numbers of throws and results by teams and match.

\begin{tabular}{|c|c|c|c|c|}
\hline Competition & Score & Team & No Throw & $\%$ Goal \\
\hline \multirow{8}{*}{$\begin{array}{c}\text { European } \\
\text { Championship } 2018\end{array}$} & 29 & Spain & 48 & $58.3 \%$ \\
\hline & 23 & Sweden & 41 & $56.1 \%$ \\
\hline & 32 & France & 47 & $68.1 \%$ \\
\hline & 29 & Denmark & 47 & $61.7 \%$ \\
\hline & 23 & France & 40 & $57.5 \%$ \\
\hline & 27 & Spain & 43 & $62.8 \%$ \\
\hline & 34 & Denmark & 46 & $58.7 \%$ \\
\hline & 35 & Sweden & 58 & $60.3 \%$ \\
\hline \multirow{8}{*}{ World Championship 2019} & 22 & Norway & 44 & $50 \%$ \\
\hline & 31 & Denmark & 45 & $71.1 \%$ \\
\hline & 25 & Germany & 42 & $59.5 \%$ \\
\hline & 26 & France & 46 & $54.3 \%$ \\
\hline & 38 & Denmark & 47 & $80.9 \%$ \\
\hline & 30 & France & 43 & $60.5 \%$ \\
\hline & 25 & Norway & 45 & $71.1 \%$ \\
\hline & 31 & Germany & 39 & $66.7 \%$ \\
\hline \multirow{8}{*}{$\begin{array}{c}\text { European } \\
\text { Championship } 2020\end{array}$} & 22 & Spain & 32 & $68.8 \%$ \\
\hline & 20 & Croatia & 31 & $64.5 \%$ \\
\hline & 20 & Slovenia & 40 & $50 \%$ \\
\hline & 28 & Norway & 47 & $61.7 \%$ \\
\hline & 29 & Croatia & 49 & $59.2 \%$ \\
\hline & 28 & Norway & 49 & $57.1 \%$ \\
\hline & 34 & Spain & 41 & $68.2 \%$ \\
\hline & 32 & Slovenia & 39 & $69.2 \%$ \\
\hline \multicolumn{2}{|c|}{$\begin{array}{r}28.04 \pm 4.79 \\
\text { ANOVA (sig) } 1.890 \mathrm{f}(0.542)\end{array}$} & & $\begin{array}{r}43.71 \pm 5.5 \\
176 \mathrm{f}(0.590)\end{array}$ & \\
\hline
\end{tabular}

In the chi-square test analysis (Table 4), 13 significant relationships were found $(p<0.05)$. The results of the throws was related to distance $(125.39, p<0.001)$ and the type of throw used $(12.62, p<0.01)$. In addition, distance was related to arm build (92.84, $p<0.001)$, jump/support $(459.45, p<0.001)$, the type of throw $(62.01, p<0.001)$, the step cycle (564.80, $p<0.001)$, the supporting foot $(26.91, p<0.001)$ and match result $(14.27$, $p<0.05)$. Additionally, arm build was correlated with the jump/support variable (71.69, $p<0.001)$ and the supporting foot $(33.49, p<0.01)$. The jump/support variable was related to the step cycle $(198.92, p<0.001)$ and the supporting foot $(20.32, p<0.001)$. Finally, the supporting foot had correlation to the step cycle $(56.74, p<0.001)$.

Table 4. Pearson chi-Square test between all variables.

\begin{tabular}{ccccccc}
\hline$x^{2}$ & Distance & Overarm & Jump/Support & Type of Throwing & Steps Cycle & Supporting Foot \\
\hline Result of throw & $125.39^{* * *}$ & & & $12.62^{* *}$ & & \\
Distance & & $92.84^{* * *}$ & $459.45^{* * *}$ & $62.01^{* * *}$ & $564.80^{* * *}$ & $26.91^{* * *}$ \\
Overarm & & $71.69^{* * *}$ & & $198.92^{* * *}$ & $33.49^{* *}$ \\
Jump/support & & & & & $56.72^{* * *}$ \\
Steps cycle & & & & & \\
Match score & $14.27^{*}$ & & & & \\
\hline
\end{tabular}

$$
{ }^{*} p<0.05 .{ }^{* *} p<0.01 .{ }^{* * *} p<0.001 .
$$

Between the result of the throw and distance, a positive and negative correlation exists in most of the categories of each variable (Table 5). The following significant relationships were found between the result of a throw and certain variables: block and $9 \mathrm{~m}(\mathrm{z}=6.5)$; goal and $6 \mathrm{~m}(\mathrm{z}=5.7)$; out and $9 \mathrm{~m}(\mathrm{z}=4)$; save and $9 \mathrm{~m}(\mathrm{z}=3.9)$; between hip and arm position and $6.9(\mathrm{z}=7.9)$; jump throw and $6 \mathrm{~m}(\mathrm{z}=13.8)$; winner teams and middle field zone throw $(\mathrm{z}=2.9)$. 
Table 5. Residual z punctuations between throw distance and significant variables.

\begin{tabular}{|c|c|c|c|c|c|c|}
\hline & & \multicolumn{5}{|c|}{ Distance } \\
\hline & & $\frac{1}{2}$ & $9 \mathrm{~m}$ & 6-9 m & $6 \mathrm{~m}$ & $7 \mathrm{~m}$ \\
\hline \multirow{4}{*}{ Result of throw } & Block & & $6.5^{* * *}$ & $2.4^{*}$ & $-6.1^{* * *}$ & $-2.2 *$ \\
\hline & Goal & $2 *$ & $-8.5^{* * *}$ & & $5.7^{* * *}$ & $3.1^{* *}$ \\
\hline & Out & & $4^{* * *}$ & & $-2.7^{* *}$ & \\
\hline & Save & $-2.3^{*}$ & $3.9^{* * *}$ & & & \\
\hline \multirow{6}{*}{ Arm position } & Low & & & & & \\
\hline & Hip & & & $7.9^{* * *}$ & $-6.5^{* * *}$ & $-2.3^{* * *}$ \\
\hline & Classic & & & $-6.7^{* * *}$ & $4.5^{* * *}$ & $2.3^{* * *}$ \\
\hline & In front & & & & & \\
\hline & Back & & & & 2.3 & \\
\hline & Rectified & & & & & \\
\hline \multirow{2}{*}{ Jump/Support } & Support & $4.9^{* * *}$ & $-2 *$ & $3.8^{* * *}$ & $-13.8^{* * *}$ & $18.6^{* * *}$ \\
\hline & Jump & $-4.9^{* * *}$ & $2 *$ & $-3.8^{* * *}$ & $13.8^{* * *}$ & $-18.6^{* * *}$ \\
\hline \multirow{2}{*}{ Type of throw } & Strong & $-5.2 * * *$ & $3.7^{* * *}$ & $3.7^{* * *}$ & $-5^{* * *}$ & \\
\hline & Skill & $5.2^{* * *}$ & $-3.7^{* * *}$ & $-3.7^{* * *}$ & $5^{* * *}$ & \\
\hline \multirow{2}{*}{ Match score } & Winner & $2.9 * *$ & & & & \\
\hline & Loser & $-2.9 * *$ & & & & \\
\hline
\end{tabular}

Note: m: metres; ${ }^{*} p<0.05 .{ }^{* *} p<0.01 .{ }^{* * *} p<0.001$.

Analysis of the step cycle (Table 6) shows the high z scores of throws from from $7 \mathrm{~m}$ and zero steps $(z=22.4)$ and supports the hypothesis that throws taken with zero steps are successful $(z=14.0)$.

Table 6. Residual z punctuations step cycle and significant variables.

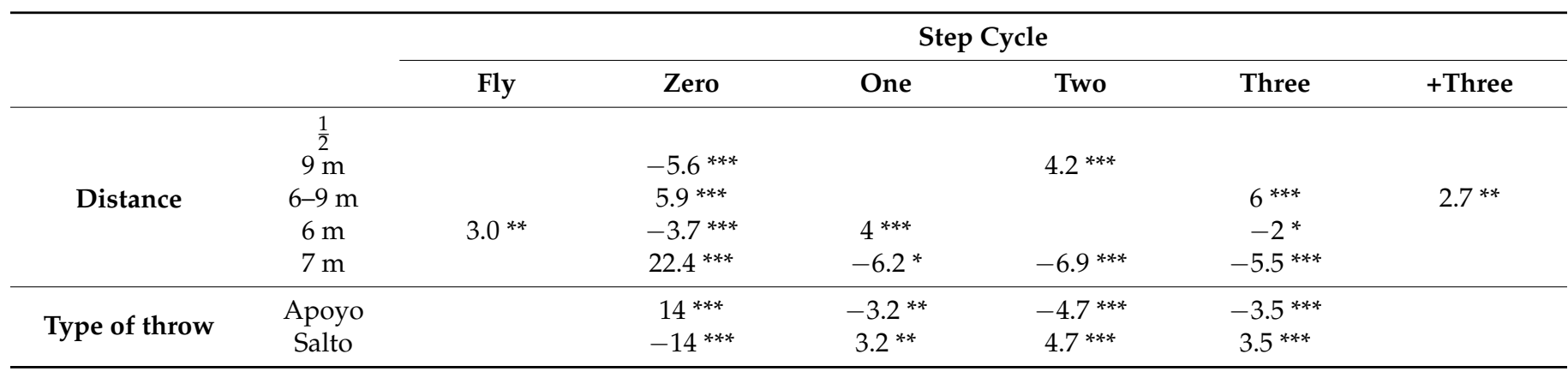

Note: m: metres; ${ }^{*} p<0.05 .{ }^{* *} p<0.01 .{ }^{* * *} p<0.001$.

\section{Discussion}

The aims of this research were to analyse the determinant factors that affected throws in handball, their effectiveness and their relationships between the variables that defined the results of throws in handball competitions of the elite male category. This study was framed by the study of match analysis [24,34-36].

The results highlight that the effectiveness of a throw is predetermined by the throwing distance and the type of throw. Equally, relationships exist between the throwing distance and all the other variables.

Originally, we found a relationship between throwing distance and its result. Similarly, Avila (2018) [24], Blanco García (2012) [37] and Almeida et al. (2019) [8] observed that throwing from six metres has a positive relationship with goal achievement, compared to throwing from nine metres, where that relationship is negative [38].

Furthermore, significant relationships have been identified with throwing distance and the result of a throw. A throw, when performed from the middle distance $(9 \mathrm{~m})$ and 
between lines (6-9 $\mathrm{m}$ ) needs to be strong and powerful so that it can take the defence by surprise $[1,39,40]$.

Equally, the relationship between the throwing distance and type of throw is brought to light. This fact is also proven in other team sports [34-36,41]. Additionally, the throw with the classic technique is the most used in throws from distances of six metres. This type of throw allows for greater manoeuvrability and variability in the launch location [42]. Furthermore, throwing while jumping is significantly more repeated and effective in throws of short distances. This is because the player has more time to observe the goalkeeper and make the right decision [43].

The step cycle offers interesting positive relationships with throwing distance. The use of no steps is found mainly in throws made between lines (6-9 m), utilizing the factor of surprise motivated by the closeness of the defensive line. A nearby throw $(6 \mathrm{~m})$ requires a great manoeuvre speed in little space, which is why it is commonly used with a one-step throw. A two-step throw has a greater association with the distance throw $(9 \mathrm{~m})$, lending a higher inertness to the throwing action by the tagging actions of the defensive line [44]. Step cycle management training related to throwing is one of the actions that cannot be missed during the formation of a handball player $[39,40]$.

Therefore, it is important that handball coaches give importance to the variability of throwing work.

\section{Conclusions}

In terms of the descriptive analysis from the last three years, in male selection championships, the quantity of throwing in semi-finals and finals has a slight downward trend in comparison to the prior championship.

The relationships observed in the research suggest that the result of a throw depends on the distance and type of throw. The distance is relevant to most parts of a throw.

Therefore, the search for effective throwing actions motivates teams to tailor their training sessions to optimize the search for goal-scoring situations close to the handball goal. It is important to increase the training time for throwing in handball to improve throw variability.

A correct approach in the learning process is key to the education of handball players. Taking advantage of the dynamic richness step cycles offer is a skill that is essential in order to reach the highest level of offensive performance in handball, as the step cycle is an essential feature of handball that helps finish a throwing action with effectiveness.

Author Contributions: Conceptualization, J.T. and D.L.; methodology, J.T., J.L. and D.L.; validation, J.T., J.L. and E.M.-P.; formal analysis, D.L. and A.A.; investigation, D.L. and A.A.; data curation, J.T. and E.M.-P.; writing—original draft preparation, J.T.; writing—review and editing, J.L., E.M.-P., A.A. and D.L.; supervision, E.M.-P., J.T., A.A. and D.L.; project administration, D.L. and E.M.-P. All authors have read and agreed to the published version of the manuscript.

Funding: This study has been partially subsidised by the Aid for Research Groups (GR18170) from the Regional Government of Extremadura (Department of Employment, Companies and Innovation), with a contribution from the European Union from the European Funds for Regional Development.

Institutional Review Board Statement: The study was conducted according to the guidelines of the Declaration of Helsinki and approved by the Ethics Committee of CEIC Aragón (CEICA) no 10/2021.

Informed Consent Statement: Not applicable.

Data Availability Statement: Not applicable.

Conflicts of Interest: The authors declare no conflict of interest.

\section{References}

1. Granados, C.; Izquierdo, M.; Ibañez, J.; Bonnabau, H.; Gorostiaga, E.M. Differences in physical fitness and throwing velocity among elite and amateur female handball players. Int. J. Sports Med. 2007, 28, 860-867. [CrossRef] 
2. Ávila, F.M. Aplicación de un sistema observacional para el análisis del lanzamiento en balonmano en el Mundial de Francia 2001. Apunt. Educ. Física Deport. 2003, 71, 100-109.

3. Van den Tillaar, R.; Zondag, A.; Cabri, J. Comparing performance and kinematics of throwing with a circular and whip-like wind up by experienced handball players. Scand. J. Med. Sci. Sport. 2013, 23, 373-380. [CrossRef]

4. Wagner, H.; Buchecker, M.; Von Duvillard, S.P.; Müller, E. Kinematic comparison of team handball throwing with two different arm positions. Int. J. Sports Physiol. Perform. 2010, 5, 469-483. [CrossRef] [PubMed]

5. García, J.A.; Sabido, R.; Barbado, D.; Moreno, F.J. Analysis of the relation between throwing speed and throwing accuracy in team-handball according to instruction. Eur. J. Sport Sci. 2013, 13, 149-154. [CrossRef]

6. Jimenez-Olmedo, J.M.; Penichet-Tomas, A.; Ortega Becerra, M.; Pueo, B.; Espina-Agullo, J.J. Relationships between anthropometric parametres and overarm throw in elite beach handball. Hum. Mov. 2019, 20, 16-24. [CrossRef]

7. Van den Tillaar, R.; Ettema, G. Instructions emphasizing velocity, accuracy, or both in performance and kinematics of overarm throwing by experienced team handball players. Percept. Mot. Skills 2003, 97, 731-742. [CrossRef]

8. Almeida, A.G.; Merlin, M.; Pinto, A.; Torres, R.D.S.; Cunha, S.A. Performance-level indicators of male elite handball teams. Int. J. Perform. Anal. Sport 2019, 20, 1-9. [CrossRef]

9. Wagner, H.; Pfusterschmied, J.; von Duvillard, S.P.; Müller, E. Performance and kinematics of various throwing techniques in team-handball. J. Sports Sci. Med. 2011, 10, 73-80.

10. Wagner, H.; Pfusterschmied, J.; Tilp, M.; Landlinger, J.; von Duvillard, S.P.; Müller, E. Upper-body kinematics in team-handball throw, tennis serve, and volleyball spike. Scand. J. Med. Sci. Sport. 2014, 24, 345-354. [CrossRef]

11. Aguilar-Martínez, D.; Chirosa, L.; Martín, I.; Cuadrado-Reyes, J. Effect of power training in throwing velocity in team handball. Rev. Int. Med. Cienc. Act. Física Deport. 2012, 12, 729-744.

12. Tuquet, J.; Zapardiel, J.C.; Saavedra, J.M.; Jaén-Carrillo, D.; Lozano, D. Relationship between Anthropometric Parametres and Throwing Speed in Amateur Male Handball Players at Different Ages. Int. J. Environ. Res. Public Health 2020, 17, 7022. [CrossRef]

13. Gorostiaga, E.M.; Granados, C.; Ibáñez, J.; Izquierdo, M. Differences in physical fitness and throwing velocity among elite and amateur male handball players. Int. J. Sports Med. 2005, 26, 225-232. [CrossRef]

14. Marques, M.C.; van den Tilaar, R.; Vescovi, J.D.; Gonzalez-Badillo, J.J. Relationship between throwing velocity, muscle power, and bar velocity during bench press in elite handball players. Int. J. Sports Physiol. Perform. 2007, 2, 414-422. [CrossRef]

15. Debanne, T.; Laffaye, G. Predicting the throwing velocity of the ball in handball with anthropometric variables and isotonic tests. J. Sports Sci. 2011, 29, 705-713. [CrossRef]

16. Ettema, G.; Gløsen, T.; Van Den Tillaar, R. Effect of Specific Resistance Training on Overarm Throwing Performance. Int. J. Sports Physiol. Perform. 2008, 3, 164-175. [CrossRef] [PubMed]

17. Ferrari, W.R.; Dos Santos, J.V.; Vaz, V.P.S. Offensive process analysis in handball: Identification of game actions that differentiate winning from losing teams. Am. J. Sports Sci. 2014, 2, 92-96. [CrossRef]

18. Ferrari, W.; Vaz, V.; Sousa, T.; Couceiro, M.; Dias, G. Comparative analysis of the performance of the winning teams of the handball world championship: Senior and junior levels. Int. J. Sports Sci. 2018, 8, 43-49. [CrossRef]

19. Vilar, L.L.; Araujo, D.; Davids, K.; Button, C. The Role of Ecological Dynamics in Analysing Performance in Team Sports. Sport. Med. 2012, 42, 1-10. [CrossRef]

20. Anguera, M.T.; Hernández-Mendo, A. Metodología observacional y psicología del deporte: Estado de la cuestión. Rev. Psicol. Deport. 2014, 23, 103-109.

21. Ortín, F.J.; Olmedilla, A. La utilización de registros para la mejora del comportamiento táctico en deportistas de equipo. Rev. Psicol. Deport. 2003, 12, 95-105.

22. Travassos, B.; Gonçalves, B.; Marcelino, R.; Monteiro, R.; Sampaio, J. How perceiving additional targets modifies teams' tactical behavior during football small-sided games. Hum. Mov. Sci. 2014, 38, 241-250. [CrossRef] [PubMed]

23. Araújo, D.; Davids, K. Team synergies in sport: Theory and measures. Front. Psychol. 2016, 7, 1449. [CrossRef] [PubMed]

24. Ávila, F.M.; Chirosa, L.J.; Ureña, A.; Lozano, D.; Ulloa, D. Evaluation of tactical performance in invasion team sports: A systematic review. Int. J. Perform. Anal. Sport 2018, 18, 195-216. [CrossRef]

25. Saavedra, J.M.; Pic, M.; Lozano, D.; Tella, V. The predictive power of game-related statistics for the final result under the rule changes introduced in the men's world water polo championship: A classification-tree approach. Int. J. Perform. Anal. Sport 2020, 20, 31-41. [CrossRef]

26. Gabin, B.; Camerino, O.; Anguera, M.T.; Castañer, M. Lince: Multiplatform sport analysis software. Procedia-Soc. Behav. Sci. 2012, 46, 4692-4694. [CrossRef]

27. Hernández-Mendo, A.; Castellano, J.; Camerino, O.; Jonsson, G.; Blanco-Villaseñor, Á.; Lopes, A.; Anguera, M.T. Programas informáticos de registro, control de calidad del dato, y análisis de datos. Rev. Psicol. Deport. 2014, 23, 111-121.

28. Blanco-Villaseñor, Á.; Lopez-Losada, J.; Anguera, M. Data analysis techniques in observational designs applied to the environmentbehaviour relation. Medio Ambient. Comport. Hum. 2003, 4, 111-126.

29. Fernández, J.; Camerino, O.; Anguera, M.T.; Jonsson, G.K.; Fernandez, J.; Camerino, O.; Anguera, M.T.; Jonsson, G.K.; Fernández, J.; Camerino, O.; et al. Identifying and analyzing the construction and effectiveness of offensive plays in basketball by using systematic observation. Behav. Res. Methods 2009, 41, 719-730. [CrossRef]

30. Peterson, R.A.; Kim, Y. On the relationship between coefficient alpha and composite reliability. J. Appl. Psychol. 2013, 98, 194-198. [CrossRef] 
31. George, D.; Mallery, P. IBM SPSS Statistics 26 Step by Step: A Simple Guide and Reference; Routledge: London, UK, 2019; ISBN 0429616325.

32. Koo, T.K.; Li, M.Y. A Guideline of Selecting and Reporting Intraclass Correlation Coefficients for Reliability Research. J. Chiropr. Med. 2016, 15, 155-163. [CrossRef]

33. Landis, J.R.; Koch, G.G. The measurement of observer agreement for categorical data. Biometrics 1977, 33, 159-174. [CrossRef]

34. Drezner, R.; Lamas, L.; Farias, C.; Barrera, J.; Dantas, L. A method for classifying and evaluating the efficiency of offensive playing styles in soccer. J. Phys. Educ. Sport 2020, 20, 1284-1294.

35. Castellano, J.; Casamichana, D.; Lago, C. The use of match statistics that discriminate between successful and unsuccessful soccer teams. J. Hum. Kinet. 2012, 31, 139-147. [CrossRef] [PubMed]

36. Gómez, M.A.; Lago-Peñas, C.; Viaño, J.; González-Garcia, I. Effects of game location, team quality and final outcome on game-related statistics in professional handball close games. Kinesiology 2014, 2, 249-257.

37. Blanco García, P. The observational analysis of performance in the handbalís throwing of the Spanish promises selection. J. Sports Sci. 2012, 8, 83-92.

38. Antúnez, A.; Ureña, V.; Velandrino, A.; García-Parra, M. Valoración de la efectividad de interceptación com éxito de la portera de balonmano ante el lanzamiento trás la aplicación de un programa perceptivo-motor. Rev. Int. Cienc. Deporte 2004, 4, 192-203.

39. Rivilla, J.; Martínez, I.; Grande, I.; Sampedro-Molinuevo, J. Relation between general throwing tests with a medicine ball and specific tests to evaluate throwing velocity with and without opposition in handball. J. Hum. Sport Exerc. 2011, 6, 414-426. [CrossRef]

40. Zapardiel, J.C.; Vila Suárez, H.; Manchado, C.; Rivilla García, J.; van den Tillaar, R. Effect of opposition and effectiveness of throwing from first and second line in male elite handball during competition. Kinesiol. Slov. 2019, 25, 35-44.

41. Ibáñez, S.; Feu, S.; García, J.; Parejo, I.; Cañadas, M. Shot differences between professional (ACB) and amateur (EBA) basketball teams. Multifactorial study. Rev. Psicol. Deport. 2009, 18, 313-317.

42. Gutiérrez-Dávila, M.; Ortega-Becerra, M.; Párraga, J.; Campos, J.; Rojas, J. Variabilidad de la secuencia temporal de la cadena cinética en el lanzamiento en balonmano. Rev. Int. Med. Cienc. Act. Física Deport. 2011, 11, 455-471.

43. Carbonell, V.; Fontaina, S.; Ramírez, A.G. Estudio de las acciones técnico-tácticas realizadas por los porteros de balonmano ante los lanzamientos de pivote. J. Sports Sci. 2018, 14, 1-8.

44. Lozano, D.; Camerino, O.; Hileno, R. Interacción dinámica ofensiva en balonmano de alto rendimiento. Apunt. Educ. Fis. Deport. 2016, 3, 90-110. [CrossRef] 